\title{
HAKEMLERIN MESULYETI
}

\section{Prof. Dr. Hikmet BELBEZ}

Hemen bütün devletler şahıslara hususi bir ihtilâfın hallini, kaza yetkisini haiz mahkemeler yerine üçünciu şahıslara bırakmak hakkını tanumislardır (1). Bu tahkim usulünün leh ve aleyhinde bir çok mütalâalar ileri sürülmüşsür. Lehte söylenen hususları bu usulün çabuk, ucuz ve sade olması şeklinde hulâsa edebiliriz (2). Bu usulün aleyhinde olarak ortaya atılan en mühim nokta da, bunun sui istimallere çok müsait olduğudur (3).

Bu sui istimaller iki bakımdan mevzuu bahis olmaktadir:

1 - Hakemier gok kere kendilerini, onlam tayin etmis olan tarafin avukatı farz etmekte ve o suretle hareket etmektedirler (4). Bunun neticesi olarak taraflardan birini tesahüp ve iltizam edici kararlarm verildiği maalesef vakidir.

2 - Tahkim usuliunün sui istimaline ikinci misal de, hakemlerin üzerlerine almış olduklam vazifenin ifasında ihmal ve teseyyüp göstermeleri ve bu suretle kusurlariyle taraflam mutazarrur edebilmeleridir.

Hakem kararlarinin ancak mahdut ve muayyen sebeplerden dolayı temyizen nakz edilebilmeleri (5), binaenaleyh kararlarn Yargitayca esastan tetkik imkânının ortadan kalkmış bulunması, bu çeşit suiistimalleri kolaylastırmaktadir (6).

(1) Rudolf Pohle, Schiedsvertrag, Rechtsvergleichendes Handwörterbuch für das Zivil - und Handeisrecht, cilt 6, s. 159 vdd.

(2) S. S. Ansay, Hukuk Yarglama Usulleri, 1948, s. 311.

(3) Leo Rosenberg, Lehrbuch des deutschen Zivilprozessrechts, 1949, s. 766.

(4) Leo Rosenberg, agy.

(5) HMUK, m. 533: "Hakemlerin kararı ancak aşağıdaki hallerde temyizen na, kiz olunur :

1. Tahkim müddetinin inkızasından sonra karar verilmig olması,

2. Talep edilmemiş bir șey hakkında karar verilmesi,

3. Hakemlerin selâhiyetleri dahilinde olmiyan meseleye karar vermeleri,

4. Hakemlerin, iki tarafin iddialarından her biri hakkanda karar vermemeleri.

Keza bak: Temyiz Tic. Dairesi 14. 11. 1938 tarihli karar; Imran Oktem, Hukuk - Usuli - muhakemeleri Kanunu Içtihatlar, 1943, s. 420.

(6) Bu itibarla Adalet Bakanlığnnca yeniden hazırlanmis olan Hukuk Usulit Muhakemeleri Kanunu projesinde Yargitayca daha geniş olçüde tetkik ve nakız selâhiyetinin tanımmı olmasında isabet vardis. 
$\mathrm{Bu}$ durum, hakl olarak; hakemler her türlił mesuliyetten ârimidirler? sualini ortaya çlkarmaktadır. Bu suali cevaplandırabilmek için evvelemirde hakemin hukukî durumunu, onun bu sffatının mahiyetini tayin ve tesbit etmek lâzımour.

Tahkim müessesesinde iki türlü münasebet mevzuu bahistir:

1 - Taraflar arasındaki münasebet. Taraflar arasınđaki intilâfın bir hakeme birakilması bir anlasma ile olur (compromissum). Alman hukukunun aksine olarak (7) bu anlaşmanın bizde yazll olmasl şarttir (8).

2 - Hakemlerle taraflar arasindaki münasebet. Hakem ile taraf. lar arasındaki münasebetin hukuki mahiyetini tahlil ederken hakemi hâkim olarak kabul edenler de varsa da (9), galip telakki bu münasebetin akdi bir münasebet olduğu merkezindedir (10).

Bu akdi münasebeti nevi sahsina münhasır bir akid olarak telâkki edenler vardir (11). Ancak ekseriyet bunu vekâlet ve hirmet akidterinden mürekkep akdi bir münasebet olarak vasiflandırmaktadır (12).

Hakem ile taraflar arasmdaki münasebetin bir vekâlet akdi olduğu telâkkisine karşı bazı mütalâalar ileri sürülebilir. Denebilir ki: Vekâlet akdinin tarifinden vekilin müekkili namma ve ondan aldığı salâhiyete mïsteniden ve onun hesabına hizmet ifasın kabul ettiği anlaşlır. Halbuki hakemler müstakildir ve ancak kanun ve vicdanları dairesinde hüküm vermekle mükelleftirler; bir vekil ise müekkilinin talimat ve iradesiyle bağhdır; vekâlet vazifesi jcabı olarak müekkilinin menfaatlarını korumakla mükeleftirler. Sonra, vekilin tasaruflar müekkili nam ve hesabına yapıldığına nazaran da hâkem ile onu intihap eden taraf arasindaki münasebetin vekâlet akdine kıyası kabil değildir; bilhassa iki tarafın tek hakem seçmeleri halinde bu hakemin her iki tarafm vekili addedilmesi ve her iki taraf nam ve hesabına hareket ettiğinin kabul

(7) Alman hukukunda bu anlaşma zimnen de olabilir. RGZ. (= Alman Devlet Mahkemesi Kararları Hukuk Kısmı) cilt 116, s. 89.

(8) HUMK. m. 517.

(9) J. Robert, Traite de l'arbitrage civil et commercial en droit interne, 19, ve orada gösterilen mliellifler ve kararlar. Bak: Osman Berki, Devletler Hususi Hukuku, 1949 , s. 420 .

(10) Metin içinde s. 356 vd. deki literatilure bak.

(11) Mesela J. Coldschmidt, Zivilprozessrecht, 1932, s. 270; Steln Jonas, Die Zivilprozessordnung, 1939, s. 1025 - 1026.

Her ikisi dahi, aymi yerlerde, bunun nevi sahsına münhasir olmakla beraber vekalet veya hizmet akdine benzeyen bir hususi hukuk akdi olduğunu ifade etmektedirler. Keza: Alman Devlet Mahkemesi kararı, cilt 59, s. 248.

(12) Metin içinde s. 356 vd deki literature bak. 
olunması vekâlet hükümlerine aykırı düşer. Kaldı ki hakemler de hâkimlerin reddi sebeplerine müsteniden reddolunabilirler; bu sebepler arasında hâkimin taraflardan birinin vekilliğini yapmuş olması hali de vardur; taraflardan birinin vekili olmasi takdirinde bu hal onun reddini müstelkim iken onunla taraflar arasındaki münasebetin vekâlet addedilmesine imkân olamaz.

Mesele u̇zerinde biraz durulursa bu iddiaların varid olmadığ̊ görülür. Vekâlet akdinin tarifinden filhakika vekilin mïekkili nam ve hesabına ve ondan aldığı salâhiyete müsteniden hizmet ifasını kabul ettiği anlaşılır. Hakemlerde de durum aynen böyledir. Hakem, hâkim değildir; o salâhiyetlerini hâkim gibi kanundan almaz, tahkim anlaşmasına dayanır ve o taraflarn miisterek vekili sufatiyle iş görür. hizmet ifa eder. Hakeme verilmis talimat da vardur $\mathrm{ki}$ bu da tahkim anlaşmasıdır. Hakem, tatbik ve takip olunacak usul bakımından dahi taraflarca kendisine verilecek talimata uymak mecburiyetindedir. Hakem öyle bir vekildir $\mathrm{ki}$, salâhiyetleri tahkim anlaşması ile muayyen ve mukayyettir.

Taraflarm tek bir hakem intihap etmeleri halinde de bu hakemin her iki tarafında vekili addedilmesinde ve her iki taraf nam ve hesabuna hareket etmesinde vekâlet hüküimlerine hị̧ bir aykırılık yoktur (13). Iki kişi muayyen bir işin ifası için bir vekil tayin etmişlerdir; hakem, her iki tarafın da vekilidir.

Bir vekil olan hakem de müekkillerinin menfaatlamm korumakla mükelleftir. Ancak müekkilin menfaatlarnun himayesi demek, behemehal bir tarafı tercih, ona iltimas demek değildir. Icabeden tetkikat ve tahkikatta bulunarak ihtilaf mevzuunu anlamağa çalışmak, taraflarm iddia ve müdafaalarz üzerinde aynı itina ile durmak, hülâsa tekabbül olunan vazifeyi lâyiki veçhile ve dikkat ve ihtimamla ifa etmek de muiekkillerin menfaatun korumak demektir.

Hakimin de hâkim gibi red olunabilmesi, onun vekillik sıfatını kaldırmaz. Hakem, taraflardan biri veya bir üçüncì sahıs ve meselâ bir mahkeme tarafindan tayin edilmiş olsa dahi, bu tayin taraflar adına yapulmakta olduğundan, yine her iki tarafin vekilidir ve taraflarla hakem arasında yine akdi bir münasebet doğar (14). Vekâlet, itimada müstenit bir muamele olması itibariyle, o hakemi doğrudan doğruya intihap etmemiş olan tarafa muayyen hallerde onu vekâletten uzaklaşturmak imkânunın verilmesi kadar tabî́ bir şey olamaz.

Hakem ile taraflar arasindaki münasebetin akdi olduğu kanaatının

(13) (14) S. S. Ansay, age., s. 318, Stein - Jonas, agy.,; Rosenberg, age. s. 780. 
ittifaka yakm bir ekseriyetle hâkim olduğunu göstermek üzere aşağıdaki müellifleri ve içtihatları zikretmek istiyoruz :

Ord. Prof. Sabri Şakir Ansay, Hukuk Yarglama Usulleri adlı eseri. nin 3 üncui tabının 318 inci sayfasında sunları yazmaktadır : "... Taraflar la hakem arasındaki mïnasebet tamamiyle bir hususi hukuk münasebetj saylmaktadır.; akdin meydana gelmesi, mzadaki fesatlar vs. hususî hu kuk kaidelerine göre hal edilir... Taraflarla hakem veya hakemler arasındaki münasebeti, bir vekâlet münasebeti olarak kabul etmek doğru olur. Hakem iki tarafça tayin edilmemiş olsa dahi onlara karşı bir vekil durumunu haizdir. Ưçüncü şahıs veya yargıç tarafından hakemin tayini işi de, taraflar adına yapılmakta olduğundan, böyle bir tayin vekâlet münasebetinin inkârına sebep olamaz. Vekâlet münasebeti icabı olarak hakem hakemliği kabule mecbur değildir..."

Ord. Prof. Mustafa Reşit Belgesay da ayni fikirdedir (Hukuk Usulï Muhakemeleri Kanunu Șerhi, 2 inci tabı, cilt II, kısım III, sah. 474 vdd., keza: Devletler Hususi Hukukunda Adliye, 1938, sah. 242 vdd.). Profesör ayni yerlerde, hakem kararlammı hukukî mahiyetini tayin hususunda Fransa'da mahkeme içtihatlarnda mevcut olan kararsızlığın nihayet Fransa'da Temyiz Mahkemesinin 9 Temmuz 1928 tarihli karariyle ortadan kalktığın, Temyiz Mahkemesinin bu karan ile hakem kararlarınm mukavelevi mahiyetini açlkça kabul etmiş bulunduğunu tasrih ediyor.

Prof. Osman Berki, Devletler Hususî Hukuku, 1949, s. 421 de intiyari tahkimde mukaveleyi mahiyet görüyor.

Fransız müelliflerinden ayni fikirde olanlar: A. Weiss, Traité de droit international privé, VI, s. 29; F. Surville et F. Arthuys, Cours élémentaire de droit international privé, 1910, s. 591; Lerebours - Pigeonnière, Précís de droit international privé, 1946, s. 372; Vincent et Pénaud, Dictionnaire de droit international privé, s. 156; ve bilhassa E. Garconnet et CH. Cézar - Bru, Traité théorique et pratique de procédure civile et commerciale, 3 üncü tabi (1925), cilt VIII, s. 532, 604.

Ayni noktai nazarı kabul etmiş Fransız mahkeme iẹtihatiarı: Cour d'Ageu, 27 Août 1845 tarihli karar, Dalloz, Receuil Périodique et Critique, 1849, 2. Kasım, s. 199; Cour d'Appel Douai, 10 déc. 1901, Dalloz, Receuil Périod. et Crit., 1903, s. 129; Cour de Cassation, Chambre de Requête, 8 déc. 1914, Dalloz, Recueil Périod. et Crit. 1916, s. 194 ve bilhassa Cour de Cassation, Chambre de Requête, 9 Julliet 1928.

tsvicreli Profesör Arthur Homberger de bu mevzu hakkındaki bir yazısında (Zeitschrift für Schweizerisches Recht, 1932, s. 3 vd.) Fransadaki durumu aynı şekilde izäh ve Almanya, Belçika ve Hollandada da akdi mahiyetin ittifakla kabul edilmis olduğuna işaret ettikten osnra 
hentiz federal bir usul hukukuna kavuşmamıs olan tsviçre için de aynı neticeye variyor. Keza tsviçrede usul hukuku için klâsik bir otorite saylan Meili de taraflarla hakem arasındaki münasebetin (receptum!) akdi oldugunu tebariz ettirmektedir. (Meili, Das Internationale Civilprozessrecht auf Grund der Theorie, Gesetzgebung und Praxis, 1904).

Mukayeseli ansiklopedik bir eser olan Rechtsvergleichendes Handwörterbuch für das Zivil - und Handelsrecht de bütün dünya hukukunu mukayeseli olarak tetkik eden Rudolf Pohle (Schiedsvertrag) şu ifadeyi kullaniyor: "Hakemlik vazifesini kabul hususunda bir mecburiyet yoktur. Şukadarki bu vazifenin kabulii ile taraflarla hakem arasinda hak ve vecibeler doğuran akdi bir münasebet teessïs eder" (s. 172).

Kezalik usul hukukunda her bíri birer otorite olan su mijellifler de ayni telâkkiyi mủdafaa etmektedirler: James Goldschmidt, Zivilprozessrecht, 1932, s. 270; Adolf Schönke, Zivilprozessrecht, 5 inci tabl, 1948; ve bilhassa Leo Rosenberg, Lehrbuchh des deutschen Zivilprozessrechts, 4. tabr, 1949 ve bu sahada en büyük şerh olan Martin Jonas, Die Zivilprozessordnung, 11. tab1, 1939, cilt II, s. 1025 - 1026.

Son olarak Alman Devlet Mahkemesinin de akdi mahiyeti kabul eden bazn kararlarn :

RG. kararlar, cilt 45 , s. 251 ; cilt 59 , s. 247 ; cilt 65 , s. 175 ; cilt 74 , s. 323 ; cilt 94, s. 210; cilt 101, s. 392 .

Esasen kanun koyucusunun Tahkim babında sevk ettiği hükümlerden de ayni neticeyi çkarmak mïmkündür :

a) Kanun 516 mcl maddesinde tahkim yoluna müracaat edip etmemek hususunda taraflam tamamiyle serbest birakmıstır. Yine ayni maddede tahkimin esasının taraflar arasındaki bir anlaşma olduğu, binnetice hakemin selâhiyetlerini taraflar arasınđaki bir akitten aldığı ve böyle bir akde mïsteniden hizmet ifa ettiği ifade edilmiștir.

b) 522 inci maddeye göre hakemler, bir traflı olarak hakemi azl edemezler. Çünkü hakem her iki tarafın da vekilidir. Fakat ittifak ederlerse azil edebilirler. Hakem hâkim olsa idi, ittifakla dahi azli mevzuu bahis olamazd..

c) Red sebepleri gerçe hâkimlerin aynidir. Fakat hâkimleri bir dâvaya bakmaktan meneden hükümler de vardır. Kanun, bunlar hakemler hakkınđa tatbik ettirmemekle de hakem ve hâkim arasındaki farkı gözettiğini belli etmiştir.

d) Hakem kararlar ancak mahkemeye tevdi ve tescil edildikten, yani ona resmi bir mahiyet verildikten sonra temyiz olunabilir (Madde 532). Diğer taraftan bu kararların ancak pek mahdut dört noktadan nakz olunabilmeleri de, kanun vazmnn mahkemeler tarafindan ve- 
rilen hükümlerle hakem kararları arasında mahiyet farkı gözettiğini açıkça göstermiştir.

e) Hakem taraflara yemin ettiremez, sahitleri tahlif, imtina edenleri istima edemez (Madde 527). Çünkü hakim değildir!.

f) Hakemler ilk içtimalarmdam itibaren altı ay içinde karar vermege mecburdurlar. Aksi halde yaplan muameleler batil olur ve münazaa selâhiyteli mahkeme tarafından hal edilir. Bu müddet tarafların muvafakatlariyle uzatılabilir (Madde 529).

Hakem ile taraflar arasindaki münasebet akdi olunca, hakemin bu akdin icaplarmna aykır hareket etmesi halinde mesul olacağı da tabiidir. (15). Binaenaleyh hâkimlerin mesuliyeti hakkndaki hükümlerin hakemler hakkında tatbiki de mevzuu bahis olamaz. Kanun vazı Mukuk Usulï Muhakemeleri Kanununun hangi maddelerini tahkim işlerinde de tatbik olunacağını arzu etmişse, bunlan tahkim faslındaki babda tahdidi olarak tasrih etmiştir. Hakemleri de hâkimler gibi mesul tutmak isteseydi, bu husustaki baba da atıfda bulunurdu. Hâkimlerin mesuliyetini tanzim eden bu 10 uncu babda da bu hususta en ufak bir sarahat dahi yoktur. Bilâkis, Hâkimler aleyhine ạ̣lacak bu gibi dâvalarin her bir hâkimin derecesine göre hangi mahkemede rüyet olunacağın tahdidi bir şekilde 575 inci maddede gösterilmiştir. Bu sarih durum karşısında hâkimlerle hakemleri mesuliyet bakımından bir tutmağa imkân yoktur.

Hakemlerin mesuliyeti bahsinde nazarı itibara alınması lâzımgelen hülkümler Borçlar Kanununun $390 \mathrm{mcl}$ maddesi delâletiyle $321,98,43$ ve 44 üncù maddeleridir.

(15) Avusturya Usul Kanunu hakemlerin bu mesuliyetini açlk olarak ifade ve tesblt etmiştir (Madde 584). 